\title{
ECOLOGICAL BASIS FOR THE DISTRIBUTION AND BREEDING OF GYRFALCONS IN THE TUNDRA OF EUROPEAN RUSSIA AND PRECONDITIONS FOR SPREADING TO NEW GROUNDS
}

\author{
VLADIMIR V. MOROZOV \\ Russian Research Institute for Nature Protection, Znamenskoye-Sadki, Moscow 117628, \\ Russian Federation.E-mail: piskulka@rambler.ru
}

\begin{abstract}
Data on the distribution, numbers, and breeding biology of the Gyrfalcon (Falco rusticolus) were collected in the tundra and forest-tundra of European Russia, the Polar Ural mountains, and Yamal Peninsula from 1982 to 2009 (excluding 2003). Extensive coverage of the region and systematic monitoring of the species breeding at the interface of lowland and mountain tundra, as well as forest-tundra, allowed me to define the most crucial factors contributing to population persistence. Among those were 1) high numbers of prey, most importantly Willow Ptarmigan (Lagopus lagopus), especially at the beginning of the breeding season, 2) the presence of other bird species providing ready-made nests, and 3) the availability of suitable nesting substrate (rock cliffs, trees, or their anthropogenic analogues). Received 17 March 2011, accepted 26 April 2011.

Morozov, V. V. 2011. Ecological basis for the distribution and breeding of Gyrfalcons in the tundra of European Russia and preconditions for spreading to new grounds. Pages 229-238 in R. T. Watson, T. J. Cade, M. Fuller, G. Hunt, and E. Potapov (Eds.). Gyrfalcons and Ptarmigan in a Changing World, Volume II. The Peregrine Fund, Boise, Idaho, USA. DOI 10.4080/gpcw.2011.0222
\end{abstract}

Key words: Gyrfalcons, European Russian tundra, food, substrate, nest provider.

The Gyrfalcon (FALCO RUSTICOLUS) is the earliest breeding raptor species in the Arctic. Its breeding season starts under winter conditions while the tundra is covered with deep snow, and hard frosts and snowstorms occur regularly. Willow Ptarmigan (Lagopus lagopus) is the only food available to Gyrfalcons at that time in the tundra of European Russia. It appears that Gyrfalcons depend on Willow Ptarmigan at this crucial time of the breeding cycle, and therefore, the abundance of ptarmigan available to Gyrfalcons as they begin breeding may be a crucial factor affecting the falcon's breeding success, and perhaps deter- mines the Gyrfalcon's distribution in the Arctic. The aim of my study was to clarify if these hypotheses are true and to identify any other factors that may be significant for breeding of Gyrfalcons in the Russian Arctic.

\section{Study Areas}

The study areas were located in the northeast of European Russia, the south of Yamal Peninsula (Western Siberia), in forest-tundra, mainland lowland tundra, mountain tundra of the Polar Urals, and islands in the Arctic Ocean of the Russian Arctic and Subarctic (Figure 1). 


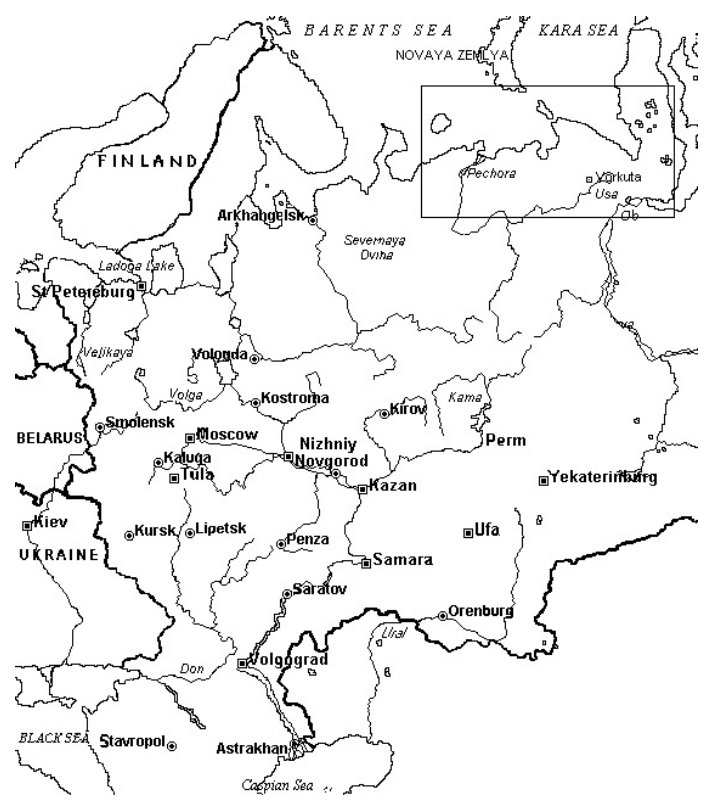

Figure 1. Map of the European part of Russia showing the study area in the northeast corner, from Kolguev Island in the west to south Yamal Peninsula in the east, and Vaygach Island in the north, to the southern tundra boundary in the south.

The tundra zone in the European part of the Russian Arctic is divided by botanists into three subzones (Gorodkov 1935). The northernmost subzone, or arctic tundra, extends throughout the archipelago of Novaya Zemlya and the northern tip of Vaygach Island. The middle subzone, or typical tundra, is distributed throughout Kolguev Island, the middle and the southern parts of Vaygach Island, and the northern part of Yugorskiy Peninsula. The southern subzone, referred to as shrub tundra or southern tundra, lies within the mainland between Kanin Peninsula and the Polar Ural mountains. The southern tundra subzone is divided into two belts - the northern belt, or short shrub-dwarf birch tundra, and the southern belt, or tall shrub-dwarf birch tundra (Gribova 1980). The forest-tundra zone spreads southwards from the southern tundra (Figure 2).

The division of tundra into subzones and belts is based on upper tier vegetation structure. In the arctic tundra, lichens, mosses, and dwarf shrubs, such as Dryas spp. and willows (Salix polaris, S. reptans, S. nummularia, S. arctica) dominate, and large areas are occupied by exposed soil (Chernov 1985). In typical tundra, dominant species of upper tier vegetation are mosses, lichens, cotton-grasses (Erioporum spp.) and sedges (Carex spp.); short shrubs occur in flood-plains only. In the southern tundra, shrubs (Betula nana, Salix pulchra, S. glauca, $S$. lapponum) are dominant in upper tier vegetation. In the northern belt of shrub tundra the height of shrubs is less than $30 \mathrm{~cm}$, while in the southern belt, the height of shrubs typically exceeds $50 \mathrm{~cm}$. Willow bushes (Salix lanata, S. phylicifolia) and small willow groves (Salix dasyclados) occupy flood-plains. In forest-tundra, both shrub tundra and a sparse forest of birch (Betula tortuosa) and fir (Picea obovata) prevail on watersheds. High and dense willow bushes and willow copses extend along the rivers.

In the Polar Ural mountains, different types of mountain tundra prevail where dominant species are dwarf birch or Vaccinium spp., or grasses, lichens and mosses.

In the southern Yamal Peninsula (Western Siberia), in the Shchuchya River basin, a sparse forest of larch with willow bushes along the river valley predominate, while different types of shrubs and cotton-grass tundra occurs on watersheds. There are larch forests in some areas on watersheds as well.

The majority of areas of long-term studies were situated in the southern belt of the shrub tundra subzone. Some study areas were situated in forest-tundra and typical tundra of Yugorskiy Peninsula, and Kolguev and Vaygach islands. A single study area was located in the arctic tundra on Vaygach Island (Figure $3)$. The eastern Bolshezemelskaya tundra monitoring area included the mountain ridge of Engane-Pe and adjoining lowland shrub tundra westwards and southwards. The area was oval, drawn from southwest to northeast between $67^{\circ} 04^{\prime}-67^{\circ} 28^{\prime} \mathrm{N}$ and $63^{\circ} 57^{\prime}-65^{\circ} 10^{\prime} \mathrm{E}$. 


\section{METHODS}

Data on the distribution, number, and breeding biology of Gyrfalcons were collected in tundra and forest-tundra of European Russia, the Polar Urals, and southern Yamal Peninsula from 1982 to 2009 (excluding 2003). Monitoring of local breeding population numbers of Gyrfalcons in the eastern Bolshezemelskaya tundra and the western Polar Urals was carried out in 1983-1993 within an area of $1400 \mathrm{~km}^{2}$ (Figure 4). Every year, all known nests were checked and new ones were discovered. A detailed investigation of all potential sites for breeding Gyrfalcons - on mountain and river cliffs, in flood-plain willow woods, and in mountain and lowland sparse forests - was carried out on foot. We looked for Gyrfalcon nests from the end of May to the beginning of June each year. At the end of June and at the beginning of July, nests were examined again to record breeding success and to ring chicks. Counts of Willow Ptarmigan were conducted at the beginning of June within the same study area. The numbers of ptarmigan breeding pairs and displaying males were counted every year within the same plot of $2.6 \mathrm{~km}^{2}$. Densities were calculated as the number of breeding pairs per $\mathrm{km}^{2}$.

A larger area of about $14,000 \mathrm{~km}^{2}$ was surveyed in 1983-1993 to find the distribution and number of Gyrfalcons nesting in different landscapes and tundra subzones (Figure 4). The survey routes and exact sites for investigation were chosen in advance using maps of scale 1:100,000. We reached the starting-point by helicopter and then floated down the river by boat or went on foot. Along the way, all cliffs and tree copses were searched. All territories occupied by Gyrfalcons were discovered, and all nests were found and mapped for the whole area. Gyrfalcon breeding density was calculated as the number of breeding pairs per $1000 \mathrm{~km}^{2}$. Some routes were followed every year, whereas others were followed periodically from time to time. In the 1980 s, distances between nests were calculated with a

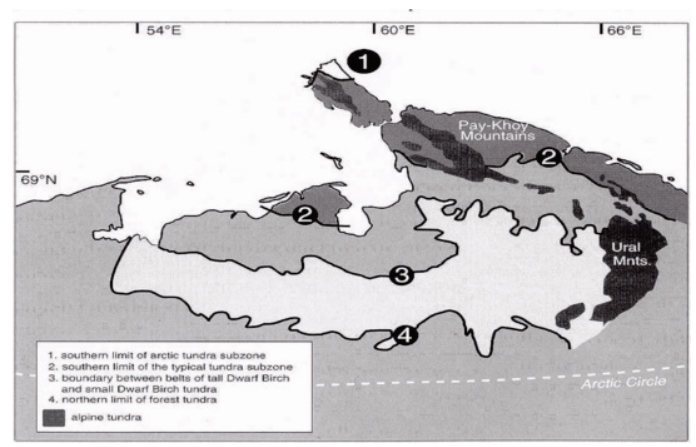

Figure 2. Map showing the distribution of tundra types, zones, and belts in the study area.

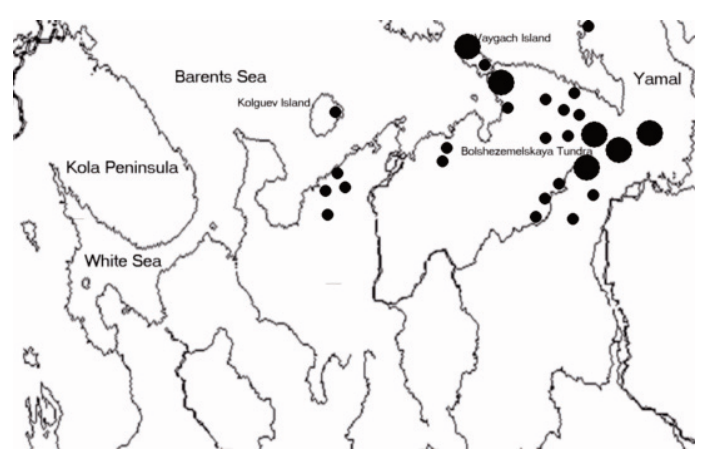

Figure 3. Map showing the location of study sites in the study area.

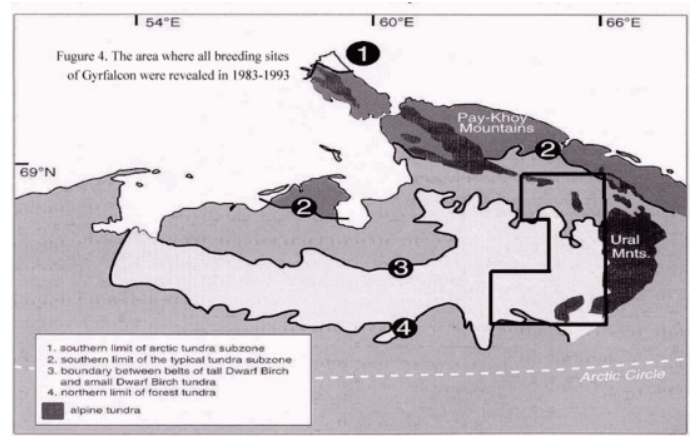

Figure 4. Map showing the area where all Gyrfalcon breeding sites were discovered during 1983-1993 in the Bolshezemelskaya tundra and the Polar Urals monitoring area. 
ruler using large-scale maps of 1:100,000 and 1:50,000 scale, whereas from 1993 we used a GPS (global positioning system, Garmin ${ }^{\circledR}$ ) to measure distances between nests.

In order to specify limits of the Gyrfalcon breeding range, several expeditions to the European Russian tundra were carried out from 1988-2010. In 1988-1992, the seashore and the central part of Yugorskiy Peninsula were surveyed; in 1991 and 1994, Vaygach Island; in 1992, the coast of Baydarata Bay on the Kara Sea; in 1995, the south of Kolguev Island, Timansky Ridge, some areas in Malozemelskaya tundra and the Chyornaya (Black) River basin in the western Bolshezemelskaya tundra; and in 2008 and 2010, the Velt River basin in Malozemelskaya tundra.

Counts of Gyrfalcons in the forest-tundra of southern Yamal Peninsula were conducted throughout 1996-1998 in the Shchuchya River valley $\left(67^{\circ} 16^{\prime}-67^{\circ} 42^{\prime} \mathrm{N}, 68^{\circ} 00^{\prime}-69^{\circ} 06^{\prime}\right.$ E). Falcons were counted along the same route every year while floating down the river and making stops every $20-30 \mathrm{~km}$ for several days. The Shchuchya River, the valleys of its tributaries, and adjoining watersheds with sparse larch forests were explored during each stop. The entire length of route-counts consisted of $820 \mathrm{~km}$ by boat and $1250 \mathrm{~km}$ on foot, $2070 \mathrm{~km}$ in total.

\section{Results}

Extensive coverage of the territory and systematic monitoring of the species over its breeding area allowed me to define the most crucial factors contributing to population persistence.

Gyrfalcons and Willow Ptarmigan.-It is well known that the Gyrfalcon depends on ptarmigan abundance in all periods of its annual cycle. However, the most sensitive period for Gyrfalcons is the pre-laying period at the beginning of the nesting cycle when Willow Ptarmigan are practically the only prey in the falcon's diet in the European Russian tundra
(Kalyakin 1989). Gyrfalcons start nesting at the beginning of April, and the pre-nesting period (displaying, mating, and nest site selection) occur earlier, usually in March. At that time in the tundra, Gyrfalcons are able to catch only Willow Ptarmigan because other migratory bird species arrive much later, and lemmings (Lemmus sibiricus, Dicrostonyx torquatus) and voles (Microtus gregalis, $M$. oeconomus, Clethrionomys rutilus, C. rufocanus) live under deep snow where they are inaccessible to the falcons. Gyrfalcons sometimes catch adult Arctic hares (Lepus timidus). However, the Arctic Hare is a very large and strong animal, and only the biggest and the most experienced female Gyrfalcons can capture them. As a result, during March, April, and up to the middle of May, the Gyrfalcon's diet may depend almost exclusively on Willow Ptarmigan.

The Gyrfalcon's reproduction and breeding success in the tundra of European Russia depended on the number of Willow Ptarmigan. The change in breeding numbers of Gyrfalcons coincided closely with the change in breeding density of Willow Ptarmigan (Figure 5), and the correlation between these two variables was significant $(\mathrm{P}<0.001$, Figure 6$)$. Notably, in 1987 and 1990, some pairs of Gyrfalcons did not breed in seasons with low numbers of Willow Ptarmigan, although they occupied their breeding territories until the end of June and visited their former nests but did not attempt to lay eggs.

Importance of Nest Substrates.-The availability of substrates suitable for nesting is a crucial factor for Gyrfalcon breeding. Gyrfalcons bred most often in nests built by other species, either on rocky cliffs along rivers and in mountains, or in trees. Rocky cliffs were usually free from snow at least in some places, such as under overhangs, in caves, or on the windward side of ledges where snow could not settle. In such places, Gyrfalcons occasionally also nested in a scrape without the benefit of a nest built by another bird species. 
Gyrfalcons did not breed in flat tundra, river slopes, steep vegetated slopes, or open ground cliffs. In March and April these sites were covered with snow. Nor did they breed on sand or peat cliffs which were easily accessible by predators.

Among 50 Gyrfalcon nests that I found in the tundra of European Russia from 1983-1989, the majority $(98 \%)$ were in nests originally built by Ravens (Corvus corax) or Roughlegged Hawks (Buteo lagopus) (Figure 7). Only one nest was in a scrape, which contrasts with Gyrfalcons breeding in other areas of the Arctic, such as Iceland, Greenland, and North America, where this type of nesting is recorded regularly (Potapov and Sale 2005). Throughout the whole study period from 1982 to 2010 , I recorded Gyrfalcons breeding in scrapes only twice. The first scrape nest was in a small deep niche on a riverine cliff. The floor of the niche was covered with dry soil dust. The second scrape nest was on a wide open ledge of an almost sheer rock cliff and was located on the ground among short grass, similar to Peregrine Falcon (Falco peregrinus) nests in tundra.

The vast majority of Gyrfalcon nests (89.3\%) that I found in the eastern Bolshezemelskaya tundra, Yugorskiy Peninsula, and the Polar Urals were situated on rocky cliffs (Figure 8). Only three $(10.7 \%)$ of 28 nests monitored from 1983-1988 were recorded in trees, even though there were enough tree species both in the Polar Urals and shrub tundra subzone and especially in the forest-tundra.

The opposite was observed in the forest-tundra of southern Yamal Peninsula where the majority of Gyrfalcons nested in trees $(86 \%$ of $n=$ 12 , Figure 9). There were very few cliffs in southern Yamal Peninsula, and few nests of other bird species built on cliffs as well. Nests built by other species in trees offered Gyrfalcons many more possibilities to find suitable nests. Nesting by Gyrfalcons on cliffs was recorded only in 1997 (Figure 10) when the number of Willow Ptarmigan in southern

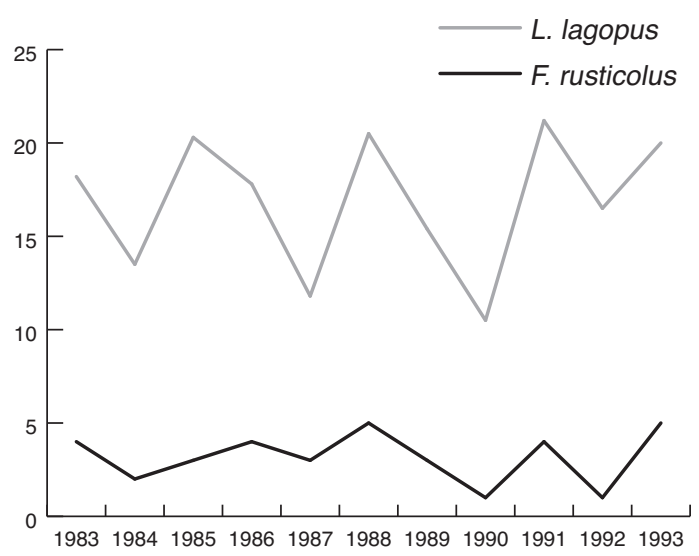

Figure 5. Graph showing the total number of breeding pairs of Gyrfalcons and the breeding density (pairs per $\mathrm{km}^{2}$ ) of Willow Ptarmigan from 1983 to 1993 in the Bolshezemelskaya tundra and the Polar Urals monitoring area.

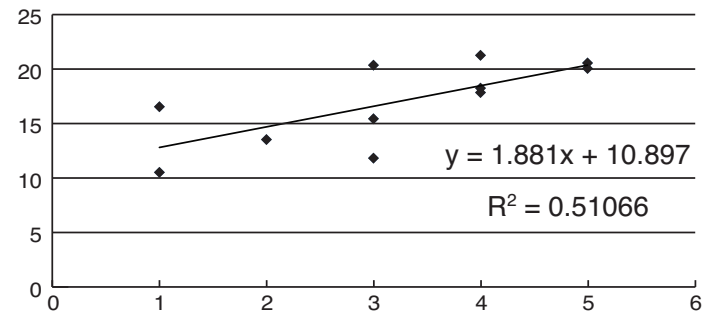

Figure 6. Graph showing the significant $(P<0.001)$ correlation between the total number of breeding pairs of Gyrfalcons (x-axis) and the breeding density (pairs per $\mathrm{km}^{2}$ ) of Willow Ptarmigan (y-axis) from 1983 to 1993 in the Bolshezemelskaya tundra and the Polar Urals monitoring area.

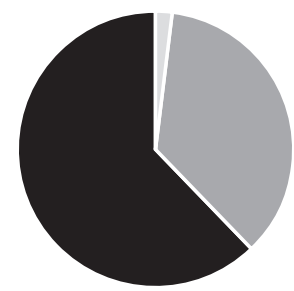

Corvus corax $62 \%$ Buteo lagopus 36\% Scrapes $2 \%$

Figure 7. Chart showing the proportions of nest substrate types used by Gyrfalcons $(n=50)$ from 1983 to 1989 in the Polar Urals of European Russia. 


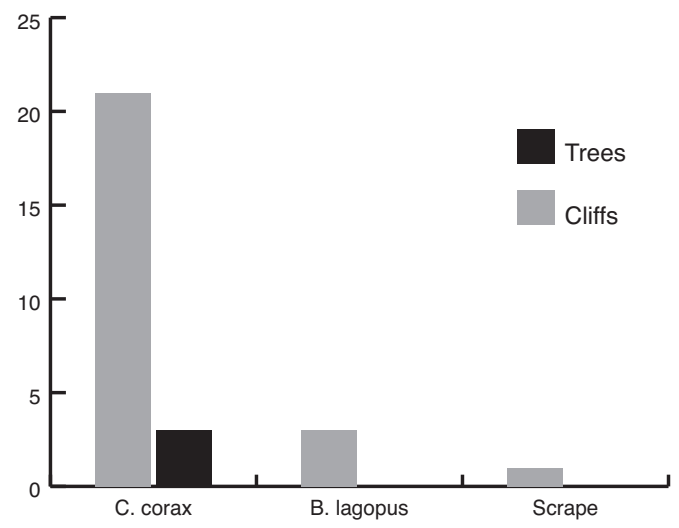

Figure 8. Graph showing the number of Gyrfalcon nests ( $n=28$ ) on cliffs and in trees, either provided by other species or scrapes made by Gyrfalcons in the eastern Bolshezemelskaya tundra and the Polar Urals monitoring area from 1983 to 1988.

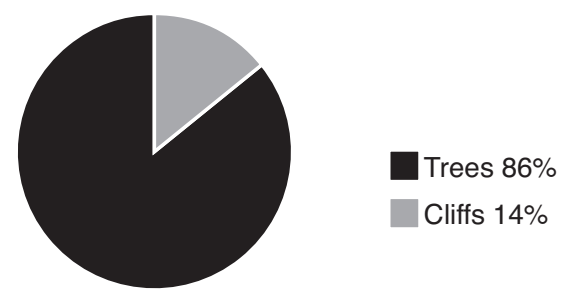

Figure 9. Chart showing the proportion of all Gyrfalcon nests ( $n=14$ ) found on cliffs and in trees in the forest-tundra of southern Yamal Peninsula from 1996 to 1998.

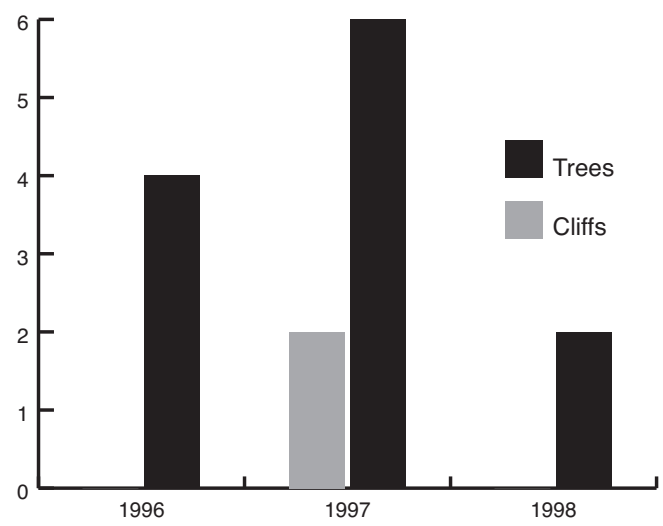

Figure 10. Chart showing the number of Gyrfalcon nests $(n=14)$ in trees and on cliffs in the forest-tundra of southern Yamal Peninsula from 1996 to 1998.
Yamal was high. Probably the number of nests in trees was not sufficient in 1997 to accommodate the number of Gyrfalcons in breeding condition, so some pairs occupied nests on cliffs which were not used in years with lower breeding numbers of Gyrfalcons.

One might think that substrate is not a leading factor when choosing a nest site. However, in the Polar Urals and in tundra to the west, Gyrfalcons preferred to nest on cliffs despite suitable alternative trees located nearby in many cases. Perhaps the reason is that nests on cliffs were more secure and comfortable because they were less often blown down or broken down by wind. This may be important during the nesting cycle when snowstorms and frost normally occur.

Gyrfalcons and Nests of Other Avian Species.-Gyrfalcons are not known to build their own nest, unlike species such as Ravens, Rough-legged Hawks, and White-tailed Eagles (Haliaeetus albicilla). Although there are references to Gyrfalcons building nests themselves (Kishinskiy 1958, Shklyarevich and Krasnov 1980), such references were not based on direct observations and were made by people who studied Gyrfalcons only after the nestbuilding period. This issue was discussed in detail by Potapov and Sale (2005), who supported the conclusion that Gyrfalcons do not build their own nest, and this has been confirmed by all scientists who studied the species during pre-nesting period.

If Gyrfalcons could build nests for themselves they would inhabit areas with abundant food even without nest providers. For example, Kolguev Island located in the Barents Sea, stands out among other Arctic areas with high numbers of Willow Ptarmigan (more than 25 breeding pairs $/ \mathrm{km}^{2}$ every year) but a lack of lemmings and voles. Thus, food supply is potentially abundant for Gyrfalcons but there are no trees, nor any nest providers such as Ravens and White-tailed Eagles. Ravens and White-tailed Eagles do not breed on the cliffs 
of Kolguev because they are covered with snow at the beginning of their breeding season (the first 10 days of April), and they are composed of sand and clay so they crumble and disintegrate in spring and are therefore not suitable for nesting, and because clutches may be easily accessible to Arctic Foxes (Vulpes lagopus) which are numerous on Kolguev Island. There are few Rough-legged Hawks on the island because their numbers are limited by the lack of small rodents, and their nests are located on the river slopes formed by sand deposits. These nests are not suitable for Gyrfalcons as they are still under snow at the beginning of the falcons' nesting cycle. Gyrfalcons do not nest in scrapes on the edges of the cliffs for the same reasons as the other species. Consequently, despite Gyrfalcons occasionally appearing in Kolguev (Morozov and Syroechkovsky Jr. 2003), they could not extend the species' breeding range to this island because of the lack of suitable nesting substrate.

With exploitation of oil fields in Kolguev occurring over the last 15 years, Rough-legged Hawks have used some of the abandoned drilling platforms as nesting sites. These nests are available for Gyrfalcons in early spring, since they are not covered with snow, nor accessible to predators. As a result, we recorded some Gyrfalcons near Rough-legged Hawks' nests (Morozov and Syroechkovsky Jr. 2003) and the first breeding by Gyrfalcons was recorded in Kolguev in 2008 (A.V. Kondratyev, pers. com.).

In the eastern tundra of European Russia, Rough-legged Hawks and Ravens were the main nest providers for Gyrfalcons (Figure 7). Both species were commonly observed breeding on rocky cliffs in mountains and along rivers, or in trees growing in river valleys. Therefore, Gyrfalcons were largely provided with nests of all kinds built by other avian species in this region.

While citing my paper (Morozov 2000) on the distribution of Gyrfalcon nests between differ-

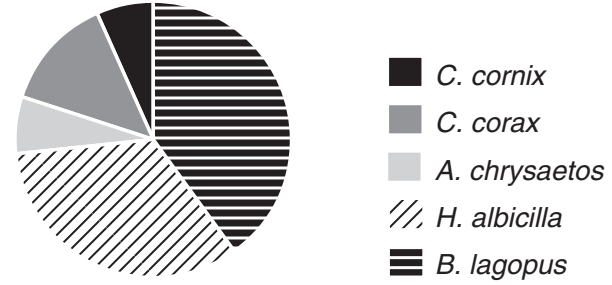

Figure 11. Chart showing the proportion of nests used by Gyrfalcons ( $n=14)$ and built by other species in the southern Yamal Peninsula from 1996 to 1998.

ent substrates, Potapov and Sale (2005, page 96) wrote that among the 50 nests I found, only one was located on a ledge while the others were found in trees. In fact, the majority of inhabited Gyrfalcon nests I found were located on cliffs and were originally built by Ravens (Figures 7 and 8).

In forest-tundra in southern Yamal, the major nest providers were White-tailed Eagles and Rough-legged Hawks (73.3\% of $n=11$ nests, Figure 11). This is quite different from Bolshezemelskaya tundra, where the diversity of raptors is lower than in southern Yamal.

It is interesting that in forest-tundra in the northeastern part of European Russia, among six Gyrfalcon nests found in 2000-2010, five $(83.3 \%)$ were placed in old Raven nests and only one was located in an old nest of a Rough-legged Hawk. One out of these six nests was placed on the cliff in an old Raven's nest, three nests were located on pylons, and two nests on abandoned drilling platforms which Ravens prefer to build their nests in.

\section{Discussion}

The most crucial factors for Gyrfalcon breeding are: 1) high numbers of prey, especially Willow Ptarmigan at the beginning of the breeding season; 2) availability of substrates (cliffs, trees, and occasionally man-made structures) suitable for nesting; and 3) availability of nests built by other avian species, 
most commonly Raven or Rough-legged Hawk, providing Gyrfalcons with nests located comfortably in trees or rocks. The Gyrfalcon breeds where all three conditions are found. If any one of these conditions is not observed, the Gyrfalcon does not breed in such an area.

It is generally accepted that the prosperity of the Gyrfalcon population depends on food supply, mainly ptarmigan species, and in European Russia, mainly Willow Ptarmigan. It is observed, for instance, on Novaya Zemlya archipelago. There are many high rocky cliffs in that archipelago and Rough-legged Hawks breed there, sometimes in high numbers. So, there are many nests that Gyrfalcons could use for breeding. However, the number of ptarmigan is very low in the archipelago, and probably only Rock Ptarmigan breed there (Strøm et al. 1994). Therefore, Gyrfalcons do not breed in Novaya Zemlya due to food shortage, despite an abundance of suitable nests.

Our study confirms this conclusion. In 19821994, the number of Willow Ptarmigan in the southern part of Bolshezemelskaya tundra was high, and enough to sustain Gyrfalcons breeding in that region. Willow Ptarmigan breeding density varied from 12 to 23 pairs $/ \mathrm{km}^{2}$, while the breeding density of Gyrfalcons ranged from 0.4 to 0.6 pairs $/ 1000 \mathrm{~km}^{2}$ in the southern belt of shrub tundra subzone and 1.0 to 2.0 pairs $/ 1000 \mathrm{~km}^{2}$ in the northern belt shrub tundra subzone. However, there was a drastic decrease in number of Willow Ptarmigan observed in 1995 all over the European tundra to the east of the Pechora River delta and as far as the Polar Urals. Willow Ptarmigan numbers were extremely low, and we recorded no more than 1-2 broods in a 3-month study period each year. This great depression lasted for six years, up to 2000, when the number of Willow Ptarmigan started a gradual increase. The loss of Willow Ptarmigan caused Gyrfalcons to completely disappear from their usual breeding areas. Not one of their breeding sites in the east of Bolshezemelskaya tundra and the Polar
Urals was occupied by Gyrfalcons in this period, whereas Rough-legged Hawks and Ravens continued to breed and provide nests. The reasons for this great and prolonged depression of Willow Ptarmigan numbers remain unknown. For the last three years, Gyrfalcons have started nesting in their traditional breeding sites again, but their numbers have not yet reached the level of the 1980s.

In the Schutchya River basin located in the forest tundra of Yamal Peninsula, Gyrfalcon numbers also underwent a decline from 1995 to 2000 , but they did not disappear completely from this area. Both resident and migratory Willow Ptarmigan winter in this area (Kalyakin 1989), so food for Gyrfalcons in the critical pre-breeding period may yet have been more abundant there than in the tundra during this period.

I believe that the availability of suitable substrates for nesting is the second crucial factor (after food availability) for Gyrfalcons breeding in the European Russian tundra. In principle, Gyrfalcons can nest without other bird species providing nests. However, if there are not enough nests built by other species, then the number of Gyrfalcons is quite low because at the end of winter there are very few suitable ledges without snow on which Gyrfalcons could lay their eggs. In regions with a milder climate, less snow cover, and the presence of cliffs, the numbers of Gyrfalcons nesting without nests provided by other species is much higher. For example, in Iceland, 52\% of 442 Gyrfalcon nests were in scrapes on ledges or caves, and only $48 \%$ were in nests built by Ravens (Cade et al. 1998). In British Columbia, Canada, 10 out of 13 Gyrfalcon nests (77\%) were located on ledges of cliffs on bare ground with no material added (Campbell et al. 1990). The availability of rocky cliffs is more important for the Gyrfalcon than tree availability because it can nest on cliffs without nests built by other bird species, whereas it is impossible to do so in trees. 
The third significant factor for Gyrfalcon breeding is the availability of nest providers. Certainly, the absence of nests built by nest providers does not exclude the possibility of Gyrfalcons breeding if there is enough food and suitable places on cliffs. However, the presence of Ravens, Rough-legged Hawks, White-tailed Eagles, and other nest providers allowed Gyrfalcons to reach comparatively high numbers in many areas, especially in Eurasia.

Taking into account these three important conditions, it is easy to explain the recent breeding distribution of Gyrfalcons in the tundra of European Russia. Within the territory located between the eastern coast of the White Sea (Kanin Peninsula) and the Polar Urals, the northern limit of the Gyrfalcon's breeding range matches the tree-line in many areas. The number of Willow Ptarmigan is high, as well as the number of nest providers (Raven, Rough-legged Hawk, White-tailed Eagle, Golden Eagle [Aquila chrysaetos], and Hooded Crow [Corvus cornix]) breeding in the same area. In some areas, the northern limit of Gyrfalcons does not reach the sea coast because there are no cliffs or trees there, despite the fact that Willow Ptarmigan are very common and Rough-legged Hawks breed on the ground there. Single Gyrfalcon breeding records on the seashore are made possible by the presence of man-made structures. Sometimes Gyrfalcons breed on wooden triangulation towers, abandoned drilling platforms, and old light beacons (light houses) in nests built by Rough-legged Hawks or Whitetailed Eagles.

On Yugorskiy Peninsula, the northern limit of the Gyrfalcons' breeding range is far from the tree-line (Figure 12) because rocky cliffs providing suitable substrates for nesting are available everywhere, Rough-legged Hawks and Ravens breed there, and the number of Willow Ptarmigan is high. However, Gyrfalcons do not reach the sea coast despite the availability of nest providers and abundant cliffs because the

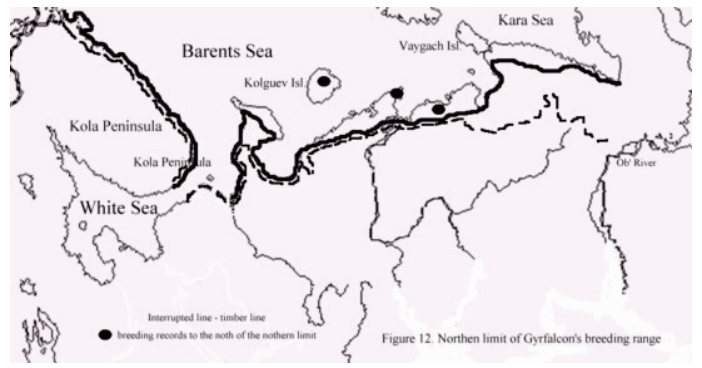

Figure 12. Map showing the northern limit of timber (tree-line), northern limit of the Gyrfalcon's breeding range according to my point of view, and breeding records found further north than this limit in 1989 (Lovetskiy Island, Petchora Delta), June 1994 (Russkiy Zavorot Peninsula), and July 2008 (Kolguev Island).

numbers of Willow Ptarmigan are low in the north of the Yugorskiy Peninsula, and rare on Vaygach Island where Gyrfalcons breed only occasionally. Perhaps a similar situation would be observed in the north of the Kanin Peninsula, where the breeding of Gyrfalcons has not yet been recorded but where there are all the necessary conditions: the number of Willow Ptarmigan is high, there are mountain ridges and cliffs along rivers, and Rough-legged Hawks and Ravens inhabit the whole peninsula. However, it is necessary to carry out an additional survey to confirm this expectation.

\section{Conclusion}

Analysis of observations reveals measures we could implement to conserve and increase the Gyrfalcon population in the tundra of European Russia and Western Siberia. Building artificial structures, with or without nests, on the seashore of the Barents and the Kara Seas and other areas where there are high numbers of Willow Ptarmigan but no trees or cliffs would allow Gyrfalcons to settle in such areas and increase the species' total numbers. The example observations on Kolguev Island are a perfect illustration of how Gyrfalcons can extend their range when habitat and food requirements are met. 


\section{ACKNOWLEDGMenTS}

Research in 1994 and 1995 in the European tundra of Russia was funded by the John D. and Catherine T. MacArthur Foundation. I would like to thank my wife Irina Rebrova for help with translation of the text.

\section{Literature Cited}

Cade, T. J., P. Koskimies, and O. Nielsen. 1998. Falco rusticolus Gyrfalcon. Birds of the Western Palearctic Update 2:1-25.

Campbell, R. W., N. K. Dawe, I. McTaggartCowan, J. M. COOPER, G. W. KaISER, AND M. C. E. MCNALl. 1990. The Birds of British Columbia, vol. 2: Nonpasserines: Diurnal Birds of Prey through Woodpeckers. University of British Columbia Press, Vancouver, Canada.

Chernov, Yu. I. 1985. The Living Tundra. Cambridge University Press, Cambridge, UK.

GoRodKov, B. N. 1935. [Vegetation of the Tundra Zone of the USSR.]. Nauka, Moscow-Leningrad. (In Russian).

GriBova, S. A. 1980. [Southern tundra]. Pages 29-44 in S. A. Gribova, T. I. Isachenko, and E. M. Lavrenko (Eds.). [The vegetation of the European part of USSR]. Nauka, Leningrad, Russia (in Russian).

KALYAKIN, V. N. 1989. [Birds of prey in ecosystems of the extreme North]. Pages
51-112 in Yu. I. Chernov (Ed.). [Birds in the Natural Communities of the Tundra Zone]. Nauka, Moscow, Russia (in Russian).

KISHINSKIY, A. A. 1958. [The biology of the Gyrfalcon Falco gyrfalco gyrfalco in the Kola Peninsula]. Scientific Notes of Moscow State University, 197. Ornithology 1: 61-75 (in Russian).

Morozov, V. V. 2000. [Ecological basis and ways of distributing the Gyrfalcon Falco rusticolus in the tundras of the European part of Russia]. Russian Journal of Ornithology, express-issue 95:3-11 (in Russian).

Morozov, V. V., AND E. E. SyroechKovsky, JR. 2003. [Materials on the knowledge of the bird fauna of Kolguev Island]. Ornithologia 31:9-50 (in Russian with English summary).

Potapov, E. And R. Sale. 2005. The Gyrfalcon. T. \& A. D. Poyser, London, UK.

ShKlyarevich, F., AND YU. KRASNOV. 1980. [The biology of the Gyrfalcon (Falco gyrfalco gyrfalco L.) in the Kola Peninsula]. Pages 17-26 in V. A. Zabrodin (Ed.). [Ecology of the Birds of the Sea Coasts]. TSNIL Glavokhota, Moscow, Russia (in Russian).

Strøм, H., I. J. ØIEN, J. Opheim, E. A. Kuznetzov, and G. V. KhaKhin. 1994. Seabird censuses of Novaya Zemlya. Norwegian Ornithological Society Report 2:138 . 